\title{
Study in pink...rash!
}

\section{Ayman Sharaf Eldin Bannaga, Stefan Wiles, Omar Rahama, Hiten Thaker}

Hull and East Yorkshire NHS Trust, Cottingham, UK

\section{Correspondence to} Ayman Sharaf Eldin Bannaga; aymanbannaga@yahoo.com

\section{DESCRIPTION}

An 18-year-old woman presented with a 1 day history of a rash that began centrally, over the abdomen, that progressed to cover the entirety of her body, most strikingly on her face. Five days prior to this presentation she suffered from fever, dry cough, abdominal pain, loose stools and myalgia. One week prior to admission she attended a convention hosted by the travelers community she belonged to; at this meeting she was exposed to three other young people with a similar history. There was no significant medical history. She took no regular medications and had no known allergies. Her last menstrual period was 10 days prior to this illness and she reported no sexual contact at all. Her mother had been against childhood vaccinations due to the adverse publicity associated with them. An examination revealed pulse of $110 \mathrm{bpm}$, normal blood pressure and fever at $38.4^{\circ} \mathrm{C}$. She was alert with evidence of bilateral conjunctivitis, bilateral posterior cervical lymphadenopathy, mild epigastric tenderness and a striking widespread erythematous maculopapular rash covering all the

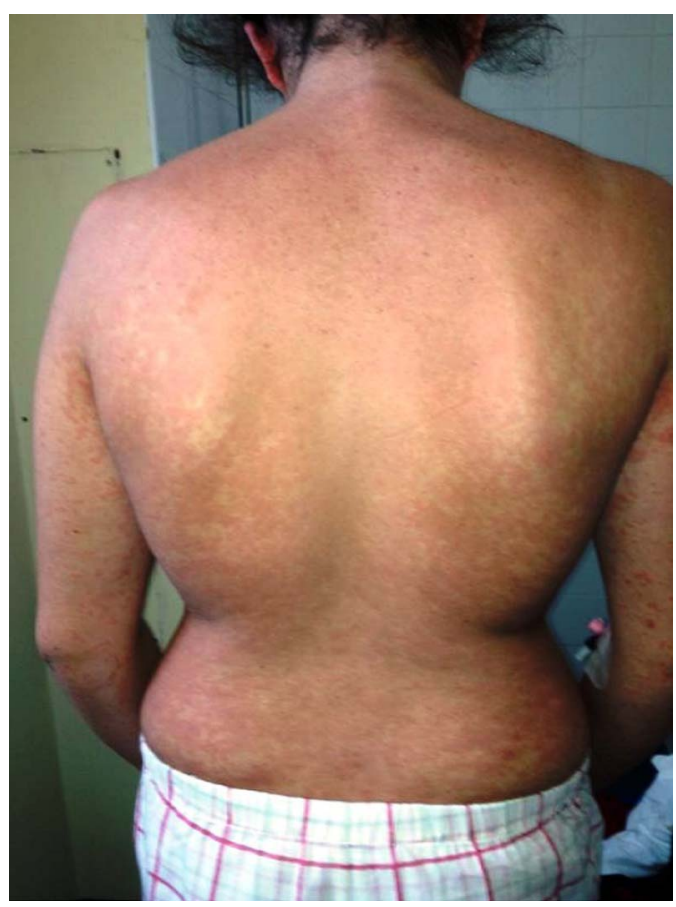

Figure 1 Confluent erythematous maculopapular rash involving the whole of the posterior aspect of the trunk. body (figure 1). Apart from a slightly raised alanine transaminase and $\mathrm{C}$ reactive protein all haematological and biochemical markers were normal, with a normal chest X-ray and blood cultures showed no growth. A viral serology was positive for measles IgM while other serological tests for HIV, cytomegalovirus, Epstein-Barr virus, parvovirus B19 and rubella were negative. She had good clinical outcome with no complications.

There is no specific therapy for measles and treatment is mainly supportive with fluids, paracetamol and vitamin $\mathrm{A}$. The main aims are to identify and explore the risk factors of the individual patient as well as public as a whole. Those most important for the patient are immunisation, immune status, contact and pregnancy. For the public the most pressing aspects are to identify the contacts for further management of this highly contagious infection. The most common complication of measles is pneumonia and other rarer complications are related to the host immune response like subacute sclerosing panencephalitis. ${ }^{1-3}$

\section{Learning points}

- Measles is still an important differential to consider especially in this age group.

- Important to involve the Health Protection Unit as early as possible to trace contact and other cases.

- Immunisation and health education are vital in the management of measles to control a highly contagious disease.

Competing interests None.

Patient consent Obtained.

Provenance and peer review Not commissioned; externally peer reviewed.

\section{REFERENCES}

1 Measles virus (Rubeolla). In: Mandell GL, Bennett JE, Dolin R, eds. Mandell, Douglas, and Bennett's Principles and Practice of Infectious Diseases. 7th edn. London: Churchill Livingstone, 2009:2229-36.

2 Health Protection Agency. HPA National Measles Guidelines Local \& Regional Services. 28 Oct 2010. http://www.hpa.org.uk/webc/ HPAwebFile/HPAweb_C/1274088429847

3 World Health Organisation. Manual for the laboratory diagnosis of measles virus infection. 2007. http://www.who.int/ihr/elibrary/ manual_diagn_lab_mea_rub_en.pdf
To cite: Bannaga ASE, Wiles S, Rahama O, et al. BMJ Case Rep Published online: [please include Day Month Year] doi:10.1136/ bcr-2013-201319 
Copyright 2013 BMJ Publishing Group. All rights reserved. For permission to reuse any of this content visit http://group.bmj.com/group/rights-licensing/permissions.

BMJ Case Report Fellows may re-use this article for personal use and teaching without any further permission.

Become a Fellow of BMJ Case Reports today and you can:

- Submit as many cases as you like

- Enjoy fast sympathetic peer review and rapid publication of accepted articles

- Access all the published articles

- Re-use any of the published material for personal use and teaching without further permission

For information on Institutional Fellowships contact consortiasales@bmjgroup.com

Visit casereports.bmj.com for more articles like this and to become a Fellow 